\title{
Informal Self-Employment and Poverty Alleviation: Empirical Evidence from Motorcycle Taxi Riders in Nigeria
}

\author{
Ogunrinola, I. Oluranti \\ Associate Professor of Economics \\ Department of Economics and Development Studies, Covenant University, Ota, Nigeria \\ Tel: 234-803-332-2048Ｅ-mail: rantiogunrinola@yahoo.co.uk
}

Received: July 15, 2010

Accepted: August 5, 2010

doi:10.5539/ijef.v3n2p176

\begin{abstract}
This study examines the role of an urban informal transport sub-sector; the motorcycle taxis (popularly called 'okada'), towards the provision of self-employment and income-generating opportunities for many of the urban unemployed in South West Nigeria. The data for the study was generated from a survey of 777 randomly selected auto cycle riders in two cities in Nigeria and the SPSS software aided data analyses. In addition to the descriptive analyses, two econometric models were specified and estimated using the OLS technique. The study revealed that the subsector is a high employer of young school leavers in the accident-prone job of okada riding. Earnings analyses show that $86 \%$ of the operators earn above the minimum wage level while human capital variables explain earnings distribution. Implications of the findings of the study point to the need for a more rigorous regulation of the sector to promote safety of operators and passengers.
\end{abstract}

Keywords: Okada, Self-employment, Earnings, Human capital, Motorcycle, Taxi

\section{Introduction}

Unemployment and poverty are two basic problems plaguing many developing nations of the world (ILO, 2007). High rate of open unemployment especially among the youths in developing nations is as prevalent as the rate of underemployed which are the major factors responsible for low standard of living in developing nations. Poverty is therefore widespread both in the cities and urban areas of Nigeria and other developing nations of the world (Amaghionyeodiwe, 2009). For instance, Nigeria was known to have been ranked as one of the middle-income, oil-producing countries in the late 1970s, but her ranking plummeted to that of one of the lowest-income countries in the early 1990s. Thus, in the early 2000's, Ukwu (2002) had to describe Nigeria as 'one of the poorest of the poor among the nations of the world, confronted not just with pockets of poverty, disadvantaged or marginalized areas, groups and individuals but with a situation in which most of the population exists at standards of living below those required for full development and enjoyment of individual and societal well-being.' In her effort to create jobs for the unemployed and promote economic growth, the Government of Nigeria put in place a number of economic reform programmes which have very minimal impacts on employment creation, poverty reduction and growth of the national economy (Abiola and Oladeji, 1998; Akinbobola and Saibu, 2004; Amaghionyeodiwe, 2009).

In order to provide themselves with means of support, many of the unemployed have no choice but to exploit the income and self or casual employment opportunities in the informal sector of the economy. The informal sector has thus become a major provider of employment especially in developing and transitional economies (Khotkina, 2007). The types of work available in the informal economy are diverse and multifarious. It stretches from casual and unstable employment like garbage picking, street trading, domestic help, and so on; to self-employment as master-craftsman in any given trade. While many researchers have studied the employment generation potentials of the informal sector in Nigeria (Ogunrinola, 1991; Folawewo, 2006); not much study is known to have been carried out on the income and employment generation as well as the poverty reduction implications of commercial motorcycle taxi (popularly called 'okada') operations. The study by Olufayo (2006) in this direction attends more to the issue of safety on commercial motorcycle taxis. The purpose of this study therefore is to examine how informal okada transport mode has contributed to income, employment generation and poverty reduction in selected states of South Western Nigeria. This study is organised as follows: Following this introductory part; Section 2 reviews some empirical literature, Section 3 examines the Methodology of the Study, Section 4 gives the interpretation of data while Section 5 concludes the paper.

\section{Brief Survey of Literature}

\subsection{Conceptual Framework}

Poverty is a multidimensional concept. While the World Bank (2000) defines it as 'pronounced deprivation in well-being', Haughton and Khandker (2009) maintains that poverty describes a state of 'lack of key capabilities 
which may be income or education, or poor health, or insecurity or low self-confidence or a sense of powerlessness, or the absence of rights such as freedom of speech.' In empirical literature, poverty has been measured in terms of consumption or level of income. A person is therefore regarded poor if she/he lives below a certain level of consumption or income. The World Development Report (2008) reported that $71 \%$ of Nigerians are living below the international poverty line of $\$ 1$ per day while $92 \%$ are below the $\$ 2$ a day poverty line. This can be contrasted with Ghana that has $45 \%$ and $78 \%$ of her population living below the $\$ 1$ and $\$ 2$ poverty lines respectively.

One important contributory factor to poverty is the dearth of formal employment to absorb the rural-urban migrants as well as graduates from the educational system that are unemployed and seeking wage work in the urban informal sector (Eglama and Bamidele, 1997). For most of the developing nations, the rate of unemployment has been on a rise while various policy measures aimed at restructuring the economy has destroyed more jobs than it created. The global economic crisis has also worsened the employment situation as massive layoff became inevitable as aggregate demand plummeted. An important implication of high unemployment rate in the formal sector is the rapid growth of the informal labour market that is characterised by earnings flexibility and hence high absorptive capacity for labour. In other words, both earnings and employment level in the informal sector behave in the neo-classical tradition and this makes the sector an employer of last resort for most workers who would have otherwise remained unemployed in the formal sector. Thus, the informal sector has become a source of employment generation, and hence a means of fighting poverty by many innovative micro-entrepreneurs in developing countries (Debrah, 2007, Faridi, et.al. 2011)

\subsection{Brief Survey of Empirical Literature}

The importance of the urban informal sector in the labour absorption process, on one hand and in poverty reduction on the other hand was the main focus of the study of the Russian informal economy by Khotkina (2007). The study found out that the informal economy is much larger than the formal; female employment growth doubles that of the male; and that the relatively 'low level of official wages ... compel people to seek salvation from poverty in the informal sphere of the (Russian) economy' (p.52). Contrary to the situation in an economy-in-transition like Russia, the Ghanaian informal economy, like any other informal sector in developing economies, was found to be very large and growing (Debrah, 2007). To combat unemployment and poverty, the Ghanaian government attempted an interventionist programme through the Skill Training and Employment Programme (STEP) that was targeted at the unemployed to enable them settle down as independent entrepreneurs in the informal sector after training. The programme achieved limited success as most of the trainees desired formal sector jobs, rather than settling down to informal entrepreneurship, among other mitigating factors. Like the case of Ghana, many interventionist policy targeted at the informal sector employment creation (e.g. the National Directorate of Employment in Nigeria) rarely achieve their goals due to official corruption and poor program design and implementation, among other factors (Debrah 2007).

An important factor for the success of informal sector entrepreneurial activities is the 'spontaneous entrepreneurial response to free market conditions ....' and a sense of felt need arising from a desire to profitably utilise an unemployed resource/talent for the purpose of utility maximisation. This was the case for the development of urban motorcycle taxi services in Kampala, Uganda (Kisaalita and Sentongo-Kibalama, 2007). The combined factors of worsening urban traffic, the deregulation of the energy industry which led to the high fossil fuel cost in East Africa and the sheer abundance of motorcycles and bicycles, among others, led to the development and unprecedented growth of bicycle and motorcycle taxi (called boda-boda) in Kampala and other Ugandan cities. The study, which interviewed thirty-seven boda-boda operators, found out that the operation helped to facilitate trade, improve urban transportation, and created jobs (Kamuchanda and Schmidt, 2009).

In Nigeria, studies on motorcycle taxis dwell more on the issue of safety rather than that of income and employment generation from the business. The earlier study was by Akinlade and Brieger (2003). The study relied on the hospital records of 81 motorcycle taxis accidents, as well as a survey of 480 motorcycle taxi drivers in South Western Nigeria. Other studies in Nigeria include Solagberu et. al (2006), and Olufayo, (2006). While the former examines the issue of general safety for okada users, the latter investigates the particular exposure of youths to motorcycle accidents in Nigeria. The present study investigates the impact of motorcycle taxis operation on income and employment generation as well as its effect on poverty reduction in Nigeria.

\section{Methodology of Study}

\subsection{Research Design and Sampling Procedure}

This study covered two states from the six states within the South Western Region of Nigeria. To obtain reasonably large and representative sample of respondents, a multi-stage sampling technique was adopted. In the first stage we 
selected two states (Lagos and Ogun) from the region; the second stage was the choice of Local Government Areas within the state, while the final stage was the choice of enumeration areas (EAs) within the chosen local government areas. In Lagos, Ojo Local Government Area was chosen while Ado-Odo/Ota was chosen in Ogun State. To draw up the sampling frame, the take-off points of commercial motorcycle taxis were located. Many of these were found on major roads, road junctions and local market areas.

Most of the locations have in place some form of rudimentary organisational structure with elected officials to direct the affairs of each take-off point. In such locations, each okada operator is registered and pays the regular association dues. The sampling frame therefore is made up of all registered and active members in the selected take-off points. From the sampling frame, we randomly selected $10 \%$ of listed members, subject to a maximum of 10 respondents from each location. If the selected person was not available for interview, the next person in the list was selected as replacement after a maximum of three call-backs. In all, we covered fifty-five garages in Lagos, and forty-five in Ogun State, which was expected to give us a maximum of one thousand respondents from the two states. However, at the end of the data collection exercise we had seven hundred and seventy-seven usable responses, translating to a response rate of 78 percent.

\subsection{Research Instrument and Data Collection Exercise}

The data gathering exercise was made possible through the use of structured questionnaire specifically designed for the purpose. Since okada riders are almost always on the move, (except when waiting on queue to take their turn in passenger picking) we have made the questionnaire to be very brief. The one-paged questionnaire was in three sections. Section A, was concerned with general questions relating to the main reasons why the respondents chose to be involved in this risky venture, what he would have done if alternative opportunities were available and what he intended doing later in life. Section B related to income analysis while the third section asked for the bio-data of the respondents. The data collection exercise took place in the months of September and October, 2008. Previously trained enumerators were sent to the field to administer the questionnaires after the initial visit to the officials of each selected okada garage to secure approval for the conduct of the study in that location. The reliability statistic of our data was tested using the Cronbach alpha which gave a result of $64 \%$.

\subsection{The Models and Analytical Technique}

The methods of analyses adopted for the study are two. The first is basically descriptive using frequency counts and cross-tabulations; while the second is the use of regression.

\subsubsection{Earnings Distribution Function}

Earnings analysis was carried out in order to determine the pattern as well as the influences of several explanatory variables on earnings distribution of okada riders in the study locations. The earnings analysis was based on human capital variables; migration characteristics, status of respondents (whether hired operators or owner-operators) and other relevant variables. In general, following Becker (1975) and Mincer (1974), we postulate that:

$$
\mathrm{Y}=\mathrm{f}(\mathbf{H}, \mathbf{X})
$$

Stating (1) explicitly, we have:

$$
\log Y=\delta_{0}+\alpha_{i} \mathbf{H}^{\prime}+\beta_{\mathrm{i}} \mathbf{X}^{\prime}+\varepsilon_{\mathrm{i}}
$$

Where: $\mathrm{Y}$ is the weekly earnings of the respondents; $\mathbf{H}$ is the vector of human capital variables; while $\mathbf{X}$ is a vector of personal and enterprise characteristics. For this study, the $\mathbf{H}$ variables are age of the entrepreneurs, experience and its square, the level of formal educational attainment measured as number of years spent in school, the number of years spent learning how to ride okada, and a dummy variable specifying if respondent previously learnt a trade/craft or not. The vector of $\mathbf{X}$ variables include marital status of respondents, religion, Migration status of respondents whether hired or owner-rider, accident experience of respondents and the number of such accidents since riding okada, number of hours worked per day as well as the number of days worked in the previous week.

\subsubsection{Employment Determinant Model}

The supply of efforts into the informal transport sector depends on a variety of factors. Given the level of economic activity, it is postulated that the amount of effort supplied into the okada riding business depends on the level of earnings, the amount of capital available for investment purposes as well as the personal and household characteristics of respondents. The effects of such factors were measured empirically using an employment supply function specified in line with the earlier works of Ndebbio 1987; Ogunrinola, 1991, as:

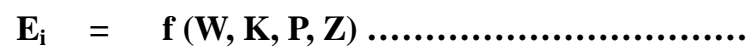


$\mathrm{Ei}$ is the number of hours worked per week by the $i$ th respondent.

$\mathrm{W}$ is the earnings per week

$\mathrm{K}$ is the level of present capital; measured as dummy variable 1, if respondent owns a motor-bike and zero otherwise.

$\mathrm{P} \quad$ is the vector of personal characteristics of riders, whether continuous $\left(\mathrm{P}_{1 \mathrm{i}}\right)$ or dummy $\left(\mathrm{P}_{2 \mathrm{i}}\right)$.

$\mathrm{Z} \quad$ is the vector of household and other variables affecting the level employment.

Two models were tried: one assuming linear relationship, and the other assuming a non- linear relationship as shown in equation (2). That is:

$$
E_{i}=\gamma+\beta_{1} w_{i}+\beta_{2} k_{i}+\sum \alpha_{j} P_{i}+\sum \delta_{j} Z_{i}+\varepsilon \ldots \ldots \ldots
$$

The non-linear form takes the Cobb-Douglas form specified as:

$$
E_{I}=\delta W_{i}^{\gamma_{1}} \prod P_{1 i}^{\tau_{j}} \prod Z_{1 i}^{a_{j}} e^{\sum P_{2 i}^{\varphi_{j}}+\sum z_{2_{i}}^{b_{j}}+K_{i}^{\gamma_{2}}} \mu
$$

Taking Logarithms on both sides of the equation to achieve linearity we have:

$$
\log E_{i}=\delta_{0}+\gamma_{1} \log W_{i}+\tau_{j} \sum \log P_{1 i}+a_{j} \sum \log Z_{1 i}+\varphi_{j} \sum P_{2 i}+b_{j} \sum Z_{2 i}+\gamma_{2} K_{i}+\varepsilon \ldots
$$

Where: $\gamma_{0}=\log \delta, \varepsilon=\log \mu$

$\mathbf{P}_{1}=$ Vector of Personal characteristics that are continuous e.g. age, experience, among others.

$\mathbf{P}_{2}=$ Vector of personal and other characteristics that are in binary/dummy forms, e.g. gender.

$\mathbf{Z}_{1}$ and $\mathbf{Z}_{2}$ are household characteristics similarly defined as $P_{1}$ and $P_{2}$.

Equations (4) and (6) are estimated and the results are as shown in Table 4.

\section{RESULTS AND DISCUSSIONS}

\subsection{Some Characteristics of the Respondents}

Two classes of riders were encountered in the survey: the hired operators as well as the owner-riders. As shown in Table 1, the result of the survey revealed that the owner operators predominated with a figure of 430 representing $55 \%$ of total respondents while the paid-operators are 347 or $45 \%$ of the total sample. In terms of the state of origin of respondents, they were found to represent all the geopolitical zones of the country while a few were foreigners. In specific terms, 494 respondents representing $64 \%$ are from South Western Nigeria which is made up of six states of Lagos, Ekiti, Oyo, Oshun, Ondo and Ogun States; 52 and 54 respondents representing $6.7 \%$ and $6.9 \%$ of the total sample are from the South-East and South-South respectively. Respondents from the entire Northern Nigeria are 65 representing about $8 \%$ of the sample; while ten representing $1.3 \%$ of the total are non-Nigerians.

In terms of age, the okada riding business is dominated by youths. Out of the 446 persons that responded to the question on age, 264 of them representing 59\% are below the age of 30; one hundred and seventy-seven of them or $40 \%$ are aged 30-49, while the remaining $1 \%$ (just 5 of them) are over 50 years of age. Thus, the informal okada transportation business provides job mainly for the youths who would have otherwise remained unemployed in the urban labour market. In spite of their youthfulness, many of the okada riders appear to have started riding auto-cycles early in life and perhaps this accounts for why it was easy for them to take up okada riding occupation when there was no desired alternative formal sector job. About $14 \%$ of the respondents had been riding okada before age 20; while a total of over 500 of them representing $81 \%$ of the respondents indicated that they had been riding motorcycle before age 30 . The distribution of riders by status shows that $60 \%$ of those riding before age 20 are the hired operators while the remaining $40 \%$ are owner-riders. With respect to marital status of the respondents, many of them are already married. While as many as over 400 representing over $60 \%$ of respondents are already married, only $32 \%$ are single while the rest are either divorced or widowed. The married are predominant among the owners $(60 \%)$ while those that are single are almost evenly distributed between the hired operators and owners. Out of the 374 respondents that reported having children, $49 \%$ of them have $1-2$ children $39 \%$ have 3 to 4 children while the remaining $11 \%$ have at least five children. On the average however, the sampled population have about three children.

\subsection{Educational Attainment, Skill Development and Future Career Aspirations of 'okada' operators}

One important issue that this study investigated is the previous education and skill development experience of these operators prior to embarking on the informal business of motorcycle taxi riding. As shown in Table 1, only $8 \%$ of the respondents belong to the 'no schooling' category; $25 \%$ have up to primary education; $55 \%$ have completed secondary education while $12 \%$ are graduates of tertiary institutions. In terms of previous skill development, Table 2 shows that 573 of the respondents have either received training in a craft or are still in school. A further analysis of the type of skill development and training undertaken by the respondents revealed that $25 \%$ (142 persons), have received training 
in Building and allied trades; another 182 representing 32\% have been trained in Vehicle Maintenance and allied disciplines; $16 \%$ in small-scale Trading; $14 \%$ have acquired skills in Garment and Shoe manufacturing trades, while 2\% have acquired skills in various aspects of Farming and agro-processing. The hired riders constitute $41 \%$ of those with previous skills acquisition while the remaining 59\% are owner-riders. The study also enquired as to why these riders have decided to neglect the main skills learnt in favour of okada riding in the informal economy. The reason given by $67 \%$ of the respondents relates to lack of access to start-up capital. In terms of future career expectation, 488 respondents $(63 \%)$ desire to start own enterprises, $12 \%$ wants to return to school, $7 \%$ desire formal sector jobs while the rest either belong to the unclassified categories or did not respond to the question. In summary, self-employment in the informal sector is the main future career goal of the majority of the respondents while their engagement in okada riding is merely a means to that end.

\subsection{Earnings of Respondents}

This study shows that the mean monthly earning for all respondents is $\$ 38,211$. When this is disaggregated by status, the mean monthly earnings for the hired operators and owner-riders are N33,334 and $\$ 42,174$ per month respectively. In contrast, the modal monthly earnings is $\$ 20,000$ - $\$ 29,999$ income range. The owner-riders dominate this group with $63 \%$ while the hired-riders account for the remaining $37 \%$. This result suggests that the owners are better off on the average than the hired operators. This result is not surprising as the owners are expected to be earning returns both from their labour as well as the capital invested in the purchase of auto-cycles. Only $14 \%$ of the respondents earn less than $\$ 10,000$ per month, while the remaining $86 \%$ of the okada operators in our survey area are earning at least $\$ 10,000$ per month at the time when the monthly minimum wage in Nigeria was $\$ 7,500$. Of the total number of 553 respondents earning N10,000 and above, $60 \%$ of them are the owner-riders while the remaining $40 \%$ are hired operators.

Table 3 shows the regression result of the earnings function expressed in equation (2). Four regression estimates are carried out and labelled regressions 1,2,3 and 4 respectively. Eight of the variables are used in regression 1, nine in regression 2, seven in regression 3 and ten in regression 4. In regression 1, five of the variables are statistically significant at the levels indicated while the coefficient of determination measured by $\mathrm{R}^{2}$ is $12.7 \%$ and the adjusted $\mathrm{R}^{2}$ (for the degrees of freedom) is $11 \%$. In regression 2, the number of explanatory variables used was increased by an important human capital variable (Migration Status) and this increases the $\mathrm{R}^{2}$ marginally to $13.2 \%$ but the said variable is found to be insignificant statistically on its impact on earnings. In other words, both migrants and natives are not different with respect to earnings level in the okada riding business in the study areas. In spite of this, however, the two regressions thus reveal that the status of riders, educational level, okada riding experience and its square (which captures the usual non-linearity assumption in the age-earning profiles) as well as marital status are significant in their impacts on earnings. Thus, the regression estimates show that the owner-operators earn more than the hired-riders; and that education and labour market experience contribute positively to earnings, while those that are married earn less than those in the non-married category. Given the estimates of EXP2 which has the expected sign in both regressions, the results show that earnings of okada riders peak at about 19 years $(0.075 \div 0.004=18.75)$ of labour market experience (Chiang 1984).

In regression 3, we dropped those variables that did not significantly affect earnings in regressions 1 and 2 and introduced the alternate variables of age and education not used in the first two regression estimates. The impact of these modifications to the model gave an improved fit with higher levels of $\mathrm{R}^{2}$ of $22 \%$; adjusted $\mathrm{R}^{2}$ of $20 \%$ and F-statistic of 10.4. Regression 4 added three variables; (i) ACCIDENT?, which is a dummy variable indicating accident experience of riders; (ii) N_ACCIDENT, the number of accidents ever experienced; and (iii) Hours worked in the previous week. The three variables are significant in their impacts on earnings and have the expected signs. Accident variables have negative impact while the number of hours supplied have a positive impact on the level of weekly earnings. Both the $\mathrm{R}^{2}$ and the Adjusted $\mathrm{R}^{2}$ also increased to $26 \%$ and $22 \%$ respectively.

\subsection{Determinants of Labour Supply in Okada Riding Business}

Factors determining the quantity of man-hours supplied and the estimates of the coefficients of each of them are as stated in Table 4. The dependent variable is the number of hours worked in the week prior to the survey exercise (Regression 1) and the natural logarithm of the same variable (Regression 2). Out of the nine variables used in the labour supply function, it is only one in regression 1 and two in regression 2 that are statistically different from zero at the critical levels indicated. The statistically significant variables in the two regressions are earnings (both at level and in logarithm form) and the dummy variable "Learnt a Trade". Regression 1 thus shows that earnings positively influence the number of hours supplied, while those with skilled trade background supply less hours of okada riding than the others. In quantitative terms, a unit change in the level of earnings brings about a 0.001 change in weekly hours supplied. In elasticity terms (Regression 2), the degree of responsiveness of hours supplied to changes in earnings is 0.191 ; signifying an inelastic relationship. 
The negative differential coefficient of 'Learnt a Trade' variable appears plausible for the respondents concerned. Many among this class of riders (69\% among the hired riders and $80 \%$ among the owners) are in okada riding occupation to raise start-up capital. They may therefore be giving some part-time attention to the practice of skills they have previously acquired. Furthermore, some of the skilled workers among the riders take okada riding as a gap-filling occupation during the idle hours of their occupation which coincides, in most cases, with peak hours in okada riding business. Such times include the early and late hours of each day when there is a heavy human traffic of those going to and returning from work places. This brings about complementarity between the two informal sector jobs being held. In sum, while the skilled respondents among the riders supply less hours than the other category; the generality of the riders perceive the job as a mere staging posts to enable them acquire the necessary start-up capital for either their business establishment along the line of their technical skill acquisition or to enable them return to school for further studies.

\section{Summary of Findings, Policy Implications of the Study and Conclusion}

This study has brought to light several important findings. One, the commercial taxi operations is a source of employment and income for many Nigerian youths and this has shown the importance of the informal sector in the labour absorption process in the urban informal sector of South West Nigeria. The study has therefore confirmed other studies in this respect (Debra, 2007; Khotikna, 2007). Second, the earnings analysis carried out confirms that the majority of operators are earning more than the (then) minimum wage, and that, perhaps has made the sector to be attractive to many educated youths (even up to tertiary level) who would have remained openly unemployed. Third, the study confirmed that both human capital variables as well as personal and household characteristics are important statistically in the determination of earnings. The third finding is that many of the operators have acquired some technical skills prior to their engagement in the okada riding business while some of them are graduates of tertiary institutions who had to get involved in auto-cycle riding due to lack of desired formal sector employment. For those with previous skill training, the lack of financial resources to set up own enterprises is the main reason for their involvement in okada riding. Many of them are however, planning to return to the occupation of their dream as soon as they could save enough funds for start-up capital. Fourth, the study also brought out in quantitative terms the level of risk (Table 2) involved in okada operation and such level of risk affects the distribution of earnings (Table 3, Regression 4). Last, but nevertheless the least, the study has shown that earnings and the skill background of riders significantly affect the number of hours supplied into the okada riding business (Table 4).

The findings of this exploratory study have brought about some implications for policy and further research. Okada operation is one of the major providers of employment for youths who would have otherwise remained unemployed. However, the nature of job provided has been shown to be risky given the rate of accidents reported. Therefore, effective safety education and improvement in the enforcement of all safety measures by the relevant authorities are important to reduce the already high accident and fatality rates arising from okada operations. Since over $90 \%$ (Table 2) of the operators are literate, the communication of safety education is expected to be relatively easy. In addition to safety education is the need for a more rigorous enforcement of licensing requirement for the operators to ensure that only those that are qualified are certified as commercial riders. Though the commercial motorcycle operation provides a fast means of transportation in the usual urban traffic hold-up as well as provide motorable access to areas linked with bad and often flooded motorways (especially during the long rainy season in SouthWest Nigeria), yet the importance of safety cannot be overemphasised.

\section{References}

Abiola A.G. \& Oladeji, S.I. (1998). Poverty Alleviation with Economic Growth Strategy: Prospects and Challenges in Contemporary Nigeria in Nigerian Journal of Economic and Social Studies (NJESS), Vol. 40, No. 1.

Akinbobola, T.O. \& M.O.O. Saibu. (2004). Income Inequality, Unemployment, and Poverty in Nigeria: A vector Autoregressive Approach; Policy Reform; Vol. 7(3), pp. 175-183. doi:10.1080/1384128042000261800, http://dx.doi.org/10.1080/1384128042000261800

Akinlade, O.C. \& Brieger, W.R. (2003/2004). Motorcycle Taxis and Road Safety in SouthWestern Nigeria; International Quarterly of Community Health Education; Vol. 22, No 1; pp 17-31. doi:10.2190/KQPM-RJ52-4UY6-9L1Y, http://dx.doi.org/ 10.2190/KQPM-RJ52-4UY6-9L1Y

Amaghionyeodiwe, Lloyd. (2009). Economic Growth and Poverty Alleviation in Nigeria; The Icfai University Journal of Public Finance; Vol. VII, No. 2; pp. 45-68.

Chiang, A.C. (1984). Fundamental Methods of Mathematical Analysis, McGraw-Hill.

Becker, G. S. (1975). Human Capital; Columbia University Press, New York; for National Bureau of Economic Research. 
Debrah, Yaw A. (2007). Promoting the Informal Sector as a Source of Gainful Employment in Developing Countries: Insights from Ghana. International Journal of Human Resource Management; Vol. 18; No. 6, pp. 1063-1084.

Eglama, A. \& A. Bamidele. (1997). Measurement Issues in Poverty' in NES (1997): Poverty Alleviation in Nigeria; Selected Papers for the 1997 Annual Conference.

Faridi, M.Z., Chaudhry, I.S., \& M.S. Malik. (2011). Why Women are Self-Employed? Empirical Evidence from Pakistan. International Journal of Economics and Finance, Vol. 3, No. 1; pp. 198-207

Folawewo, A.O. (2006). Determinants of Informal Sector Labour Demand: An Application of Alternative Methodological Approaches to South Western States of Nigeria. Applied Econometrics and International Development, Vol. 6, No.2; pp. 147-162.

ILO. (2007). African Employment Trends. International Labour Office, Geneva.

Haughton, J. \& S.R. Khandker. (2009). Poverty + Inequality: Handbook on Poverty and Inequality. The World Bank, Washington, D.C.

Kamubanda R. \& O. Schmidt. (2009). Matatu: A Case Study of the Core Segment of the Public Transport market of Kampala, Uganda. Transport Review; Vol. 29; No.1, January. Pp 129-142.

Khotikna, Z.A. (2007). Employment in the Informal Sector. Anthropology \& Archaeology of Eurasia, Vol. 45, No. 4; pp.42-55. doi:10.2753/AAE1061-1959450403, http://dx.doi.org/10.2753/AAE1061-1959450403

Mincer, J. (1974). Schooling, Experience and Earnings. Columbia University Press, New York.

Ndebbio, J.E.U. (1987). Employment Generation and the size of Industries in Nigeria: The case of Cross Rivers State. The Nigerian Journal of Economic and Social Studies; Vol. 29, No.2 pp.149-168.

Kisaalita, W. S. \& J. Entongo-Kibalama. (2007). Delivery of Urban Transport in Developing Countries: The Case for the Motorcycle Taxi Service (boda-boda) Operators of Kampala. Development Southern Africa, Vol. 24, No.2; June. doi:10.1080/03768350701327319, http://dx.doi.org/10.1080/03768350701327319

Oguninola, I.O. (1991). Employment and Earnings in the Urban Informal Sector of Ibadan. An unpublished Ph.D Thesis submitted to the Department of Economics Obafemi Awolowo University.

Olawole, M.O., Ajala, O.A. \& O. Aloba. (2010). Risk Perception among Users of Commercial Motorcycles in Cities of SouthWestern Nigeria. Ife Psychologia, September.

Olufayo, Olu-Olu. (2006). Child Neglect, Youth Involvement in Okada Transportation Business and the Incidence of Road Accident in Ado-Ekiti. The Social Sciences, Vol. 1 (3); pp. 178-182.

Rahman. (2006). Motorcycle Injuries in a Developing Country, and the Vulnerability of Riders, Passengers and Pedestrians. Injury Prevention; Vol 12, pp. 266-268.

Solagberu, B.A., Ofoegbu, C.K.P., Nasir, A.A.; Ogundipe, O.K., Adekanye, A.O.\& L.O. Abdur-Rahman. (2006). Motorcycle Injuries in a Developing Country, and the Vulnerability of Riders, Passengers and Pedestrians. Injury Prevention; Vol 12, pp. 266-268. doi:10.1136/ip.2005.011221 PMid:16887951 PMCid:2586788, http://dx.doi.org/doi:10.1136/ip.2005.011221

Ukwu, I.U. (2002). Towards Effective Poverty Eradication Strategies in Nigeria. Centre for Development Research, Management and Training, Enugu, Nigeria.

World Bank. (2000). World Development Report: Attacking Poverty. World Bank, Washington DC.

World Development Report. (2008). Agriculture for Development. The World Bank, Washington D.C. 
Table 1. Distribution of Respondents by Status and by Personal Characteristics

\begin{tabular}{|c|c|c|c|c|c|c|c|}
\hline \multirow{3}{*}{ Main Variable } & \multirow{3}{*}{ Derived Variables } & \multicolumn{4}{|c|}{ Status of Operators } & \multirow{2}{*}{\multicolumn{2}{|c|}{ TOTAL }} \\
\hline & & \multicolumn{2}{|c|}{ Hired Operators } & \multicolumn{2}{|c|}{ Owner Operators } & & \\
\hline & & No. & Percent & No. & Percent & No. & Percent \\
\hline \multirow{6}{*}{ Age of Respondents in years } & Less than 20 & 5 & 50 & 5 & 50 & 10 & 2.2 \\
\hline & 20-29 Years & 133 & 52 & 122 & 48 & 254 & 57.04 \\
\hline & 30-39 Years & 57 & 43 & 76 & 57 & 133 & 29.75 \\
\hline & 40-49 Years & 15 & 34 & 29 & 66 & 44 & 9.84 \\
\hline & 50 Years and over & 4 & 80 & 1 & 20 & 5 & 1.11 \\
\hline & TOTAL & 214 & 48 & 233 & 52 & 447 & 100 \\
\hline \multirow{6}{*}{ Age since riding Okada } & $<20$ Years & 51 & 60 & 34 & 40 & 85 & 13.6 \\
\hline & $20-29$ years & 184 & 43 & 240 & 57 & 424 & 67.7 \\
\hline & $30-39$ years & 30 & 34 & 59 & 66 & 89 & 14.2 \\
\hline & $40-49$ years & 10 & 38 & 16 & 62 & 26 & 4.2 \\
\hline & $50 \mathrm{yrs} \&$ over & 2 & 100 & - & - & 2 & 0.3 \\
\hline & TOTAL & 277 & 44.2 & 349 & 55.6 & 626 & 100 \\
\hline \multirow{5}{*}{ Highest Formal Educational Attainment } & No formal education & 34 & 55 & 28 & 45 & 62 & 8.0 \\
\hline & Primary & 69 & 35 & 126 & 65 & 195 & 25.1 \\
\hline & Secondary & 200 & 47 & 224 & 53 & 424 & 54.6 \\
\hline & Post-Secondary & 43 & 45 & 52 & 55 & 95 & 12.3 \\
\hline & TOTAL & 346 & 44.6 & 430 & 55.4 & 776 & 100 \\
\hline \multirow{7}{*}{ Region of Origin } & South West & 236 & 48 & 257 & 52 & 494 & 63.6 \\
\hline & South East & 18 & 35 & 34 & 65 & 52 & 6.7 \\
\hline & South South & 24 & 44 & 30 & 56 & 54 & 6.9 \\
\hline & Northern Nigeria & 28 & 43 & 37 & 57 & 65 & 8.4 \\
\hline & Non-Nigerians & 3 & 30 & 7 & 70 & 10 & 1.3 \\
\hline & Non-Response & 37 & 36 & 65 & 64 & 102 & 13.1 \\
\hline & TOTAL & 347 & 45 & 430 & 55 & 674 & 100 \\
\hline \multirow{4}{*}{ Marital Status } & Married & 174 & 40 & 263 & 60 & 437 & 61.4 \\
\hline & Single & 115 & 50 & 113 & 50 & 228 & 32 \\
\hline & Divorced/Widowed & 30 & 64 & 17 & 36 & 47 & 6.6 \\
\hline & TOTAL & 319 & 44.8 & 393 & 55.2 & 712 & 100 \\
\hline \multirow{4}{*}{ No. Of Children } & $1-2$ & 74 & 40 & 109 & 60 & 183 & 49.3 \\
\hline & $3-4$ & 64 & 44 & 81 & 56 & 145 & 39.1 \\
\hline & 5 and over & 22 & 51 & 21 & 49 & 43 & 11.6 \\
\hline & TOTAL & 160 & 42.8 & 211 & 57.2 & 371 & 100 \\
\hline
\end{tabular}

Source: Author's computation from survey data. 
Table 2. Distribution of Respondents by Some Business Characteristics

\begin{tabular}{|c|c|c|c|c|c|c|c|}
\hline \multirow{3}{*}{ Main Variable } & \multirow{3}{*}{ Derived Variables } & \multicolumn{4}{|c|}{ Status of Operators } & \multirow{2}{*}{\multicolumn{2}{|c|}{ TOTAL }} \\
\hline & & \multicolumn{2}{|c|}{ Hired Operators } & \multicolumn{2}{|c|}{$\begin{array}{l}\text { Owner } \\
\text { Operators }\end{array}$} & & \\
\hline & & No. & Percent & No. & Percent & No. & Percent \\
\hline \multirow{8}{*}{$\begin{array}{l}\text { Types of Craft Learnt Before Engaging in } \\
\text { 'okada Riding }\end{array}$} & Building and Allied trades & 50 & 35.2 & 92 & 64.8 & 142 & 24.8 \\
\hline & Vehicle Repairs & 77 & 42.3 & 105 & 57.7 & 182 & 31.8 \\
\hline & Trading & 39 & 41.5 & 55 & 58.5 & 94 & 16.4 \\
\hline & Garment and Shoe Manufacturing & 39 & 50 & 39 & 50 & 78 & 13.6 \\
\hline & Farming \& Agro Processing & 5 & 46 & 6 & 54 & 11 & 1.9 \\
\hline & Miscellaneous & 9 & 32 & 19 & 68 & 28 & 4.9 \\
\hline & Schooling & 16 & 42 & 22 & 58 & 38 & 6.6 \\
\hline & ALL & 235 & 41 & 338 & 59 & 573 & 100 \\
\hline \multirow{4}{*}{ Years spent Learning Trade/Craft } & Between 1-2 Years & 50 & 48 & 54 & 52 & 104 & 34 \\
\hline & Between 3-4 Years & 73 & 47 & 81 & 53 & 154 & 51 \\
\hline & Over 4 Years & 24 & 53 & 21 & 47 & 45 & 15 \\
\hline & ALL & 147 & 49 & 156 & 51 & 303 & 100 \\
\hline \multirow{5}{*}{$\begin{array}{l}\text { Major Reason for Engaging in okada riding } \\
\text { business }\end{array}$} & $\begin{array}{l}\text { To raise money for business } \\
\text { start-up }\end{array}$ & 160 & 40 & 244 & 60 & 404 & 67 \\
\hline & Love for Self-Employment & 47 & 57 & 36 & 43 & 83 & 14 \\
\hline & Post-formal sector employment & 34 & 49 & 36 & 51 & 70 & 12 \\
\hline & No formal sector Job & 15 & 38 & 25 & 62 & 40 & 7 \\
\hline & TOTAL & 315 & 43 & 371 & 57 & 597 & 100 \\
\hline \multirow{9}{*}{$\begin{array}{l}\text { Average Monthly Earnings from Okada } \\
\text { Riding Business }\end{array}$} & Up to $\mathrm{N} 9,999$ & 68 & 73 & 25 & 27 & 93 & 14.4 \\
\hline & $\mathrm{N10,000}$ - $\mathrm{N19,999}$ & 82 & 55.8 & 65 & 44.2 & 147 & 22.8 \\
\hline & $\mathrm{N} 20,000-29,999$ & 60 & 37 & 102 & 63 & 162 & 25.1 \\
\hline & $\mathrm{N} 30,000-39,999$ & 21 & 33 & 42 & 67 & 63 & 9.8 \\
\hline & $\mathrm{N} 40,000-49,999$ & 13 & 20 & 51 & 80 & 64 & 9.9 \\
\hline & $\mathrm{N} 50,000-59,999$ & 6 & 30 & 14 & 70 & 20 & 3.1 \\
\hline & $\mathrm{N} 60,000$ and over & 39 & 40 & 58 & 60 & 97 & 15 \\
\hline & $A L L$ & 289 & 45 & 357 & 55 & 646 & 100 \\
\hline & Mean & \multicolumn{2}{|c|}{$\begin{array}{l}\$ 33,334 \\
(n=290)\end{array}$} & \multicolumn{2}{|c|}{$\begin{array}{l}N 42,174 \\
(n=357)\end{array}$} & \multicolumn{2}{|c|}{$\# 38,211$} \\
\hline \multirow{3}{*}{ Any Accident? } & No & 160 & 46.5 & 184 & 53.5 & 344 & 44 \\
\hline & Yes & 139 & 46.6 & 159 & 53.4 & 298 & 56 \\
\hline & ALL & 299 & 46.6 & 343 & 53.4 & 642 & 100 \\
\hline \multirow{4}{*}{ If Yes, how many times (N_Accident) } & Once, only & 49 & 42 & 67 & 58 & 116 & 43.4 \\
\hline & Twice, only & 39 & 50 & 39 & 50 & 78 & 29.2 \\
\hline & Three times and over & 27 & 37 & 46 & 63 & 73 & 27.4 \\
\hline & ALL & 115 & 43 & 152 & 57 & 267 & 100 \\
\hline
\end{tabular}

Source: Author's computation from survey data. 
Table 3. Regression Results of Earnings Distribution Function Among Okada Operators in Nigeria.

Dependent Variable: Natural Log of Earnings of Okada Riders in Naira

\begin{tabular}{|c|c|c|c|c|c|c|c|c|}
\hline \multirow{2}{*}{ Variables } & \multicolumn{2}{|l|}{ Regression 1} & \multicolumn{2}{|l|}{ Regression 2} & \multicolumn{2}{|c|}{ Regression 3} & \multicolumn{2}{|c|}{ Regression 4} \\
\hline & Coeffic-ient & t-statistic & Coefficient & t-statistic & Coefficient & t-statistic & Coefficient & t-Statistic \\
\hline Status: Owner =1; zero otherwise & 0.472 & $5.737 *$ & 0.470 & $5.722 *$ & 0.367 & $4.271 *$ & 0.407 & $3.997 *$ \\
\hline Educ Before Riding & 0.018 & $3.105^{* *}$ & 0.018 & $3.094 * *$ & & & & \\
\hline Present Educ. Level & & & & & 0.025 & $2.396 * *$ & 0.037 & $2.721 *$ \\
\hline Experience (EXP) & 0.075 & $2.526^{* *}$ & 0.076 & $2.543 * *$ & 0.033 & 1.202 & 0.032 & 0.728 \\
\hline Square of Experience (EXP2) & -0.004 & $-2.276^{* *}$ & -0.004 & $-2.325 * *$ & -0.003 & $-1.936 * * *$ & -0.003 & -0.975 \\
\hline $\begin{array}{lrll}\text { Period Spent } & \text { Learning to ride } \\
(\text { RIDELEARN) } & & & \\
\end{array}$ & 0.001 & 0.49 & -0.002 & -0.174 & & & & \\
\hline Age at Riding Okada (AGE_R) & 0.001 & 0.112 & 0.002 & 0.346 & & & 0.012 & $1.625 * * *$ \\
\hline Present Age (AGE_P) & & & & & 0.006 & $5.172 *$ & & \\
\hline Learn a Trade? Yes=1 & 0.090 & 0.899 & 0.126 & 1.232 & & & 0.260 & $2.071 * *$ \\
\hline Marital Status & -0.185 & $-2.108^{* *}$ & -0.192 & $-2.198 * *$ & -0.013 & -0.161 & -0.105 & -0.914 \\
\hline MIGSTAT & & & -0.131 & -1.625 & 0.108 & 1.349 & & \\
\hline Accident? & & & & & & & -0.465 & $2.671 *$ \\
\hline No. of Accidents & & & & & & & -0.006 & $-3.413 *$ \\
\hline Hours worked & & & & & & & 0.013 & $3.890 *$ \\
\hline CONSTANT & 5.964 & $28.588 *$ & 5.974 & $28.678^{*}$ & 5.482 & $28.287 *$ & 4.021 & $10.848^{*}$ \\
\hline $\mathrm{R}^{2}$ & 0.127 & & 0.132 & & 0.221 & & 0.259 & \\
\hline Adj. $R^{2}$ & 0.11 & & 0.114 & & 0.200 & & 0.224 & \\
\hline F-statistic & 7.618 & & 7.092 & & 10.4 & & 7.382 & \\
\hline Significance of $F$ & 0.000 & & 0.000 & & 0.000 & & 0.000 & \\
\hline
\end{tabular}

Note: $*$ Significant at $1 \%$ level or better

$* *=$ Significant at $5 \%$ level or better

$* * *=$ Significant at $10 \%$ level or better

Table 4. Regression Results of Labour Supply Function

\begin{tabular}{|c|c|c|c|c|}
\hline \multirow{3}{*}{ Variables } & \multicolumn{2}{|l|}{ Regression 1} & \multicolumn{2}{|l|}{ Regression 2} \\
\hline & \multicolumn{2}{|c|}{$\begin{array}{l}\text { Dependent Var: Hours of labour supplied per } \\
\text { week }\end{array}$} & \multicolumn{2}{|c|}{$\begin{array}{l}\text { Dependent Var.: Natural Log of Hours } \\
\text { supplied per week }\end{array}$} \\
\hline & Coefficient & t-statistic & Coefficient & t-statistic \\
\hline Age & -0.069 & -0.349 & & \\
\hline Ln Age & & & -0.179 & -1.118 \\
\hline Education & -0.288 & -0.896 & & \\
\hline Ln Education & & & -0.166 & -1.582 \\
\hline Weekly Earnings & 0.001 & $3.915 *$ & & \\
\hline Ln Wkly Earnings & & & 0.191 & $4.638^{*}$ \\
\hline Marital Status & -0.179 & -0.058 & -0.039 & -0.501 \\
\hline Migrant & 2.347 & 0.901 & 0.056 & 0.849 \\
\hline Status (Owner) & -0.489 & -0.188 & -0.034 & -0.519 \\
\hline Region of Origin (S.W.) & 0.656 & 0.227 & -0.007 & -0.102 \\
\hline Learnt a Trade & -2.989 & -0.990 & -0.136 & $-1.795^{* * *}$ \\
\hline Had Accident & -0.018 & -0.295 & -0.001 & -0.580 \\
\hline CONSTANT & 46.704 & $5.945^{*}$ & 3.264 & 4.916* \\
\hline $\mathrm{R}^{2}$ & 0.115 & & 0.19 & \\
\hline Adj. $R^{2}$ & 0.55 & & 0.13 & \\
\hline F-statistic & 1.931 & & 3.236 & \\
\hline Significance of F & $0.053 * * *$ & & $0.001 * *$ & \\
\hline
\end{tabular}

